\title{
Urinary testosterone-17 $\beta$-glucuronide as an indicator of androgen output in mice
}

\author{
J. P. P. Tyler, Janet Simpson and W. P. Collins \\ Department of Obstetrics \& Gynaecology, King's College Hospital Medical School, \\ Denmark Hill, London SE5 8RX, U.K.
}

\begin{abstract}
Summary. The androgenic status of female mice was assessed by measuring the concentration of testosterone-17 $\beta$-glucuronide in serial samples of unextracted urine. The subcutaneous administration of testosterone $(50 \mu \mathrm{g}$ in lauric acid ethyl ester) resulted in a significant increase $(P<0.01)$ of the mean \pm s.d. concentration of urinary testosterone-17ß-glucuronide $(25.9 \pm 6.5$ to $71.7 \pm 12.9 \mathrm{ng} / \mathrm{ml})$ within $2 \mathrm{~h}$. The 2-h values after the administration of $50 \mu \mathrm{g}$ androstenedione or $50 \mu \mathrm{g}$ dehydroepiandrosterone were $22.8 \pm 4.4$ to $81.8 \pm 7.8 \mathrm{ng} / \mathrm{ml}(P<0.001)$ and $23.4 \pm 2.7$ to $121.8 \pm 20.3 \mathrm{ng} / \mathrm{ml}(P<0.001)$ respectively. The values decreased progressively over the next $24 \mathrm{~h}$.

After the induction of superovulation with PMSG and hCG, the values for testosterone-17ß-glucuronide increased significantly $(P<0.01)$ during the periovulatory period (5-24 h after hCG injection). The mean \pm s.d. value in pregnancy was higher $(61.8 \pm 11.6 \mathrm{ng} / \mathrm{ml} ; P<0.001)$ than that in non-pregnant animals $(30.7 \pm 12.3 \mathrm{ng} / \mathrm{ml})$ and remained relatively constant between Days 1 and 16 .
\end{abstract}

\section{Introduction}

The monitoring of gonadal function in small mammals presents several problems. Recently, however, the value of measuring urinary pregnanediol-3 $\alpha$-glucuronide as an index of progestagen production has been demonstrated for serial samples from female mice (Tyler, Edwards \& Collins, 1978). This procedure has the advantage that longitudinal studies can be undertaken without apparent stress to the animals and is, therefore, potentially useful both in the laboratory and in field studies of small rodents. An index of androgenic status would also be of value since it is known that some $\mathrm{C}_{19}$ steroids may affect follicular development (Payne, Hellbaun \& Owens, 1956; Peters, Sorensen, Byskov, Petersen \& Krarup, 1970; Louvet, Harman, Schreiber \& Ross, 1975 ) and influence the rate of atresia (Payne \& Runser, 1958; Louvet, Bayard, Pujol \& Toulouse, 1976).

The aim of the present study was to assess the feasibility of monitoring androgen production in female mice by measuring the concentration of urinary testosterone-17 $\beta$-glucuronide.

\section{Materials and Methods}

\section{Animals}

Random-bred female white mice, aged 6-12 weeks and nulliparous were taken from the colony established at King's College Hospital Medical School. They were caged in groups of 5 and maintained under natural lighting-conditions (approximately $14 \mathrm{~h}$ light $/ 24 \mathrm{~h}$ ) at $23^{\circ} \mathrm{C}$ with 
unlimited access to food and water. During the experiments general disturbances and handling occurred only at the time of urine collection. Urine was collected by inverting the animal, holding both hind legs apart and gently massaging the bladder. Generally more than $40 \mu \mathrm{l}$ urine were collected from each animal and with experience 50 mice could be handled within $30 \mathrm{~min}$. Each collection (see experiments) was centrifuged before storage at $-15^{\circ} \mathrm{C}$ before assay.

\section{Radioimmunoassay of testosterone-17 $\beta$-glucuronide}

The method for measuring testosterone-17 $\beta$-glucuronide was essentially as described for pregnanediol-3 $\alpha$-glucuronide (Tyler et al., 1978) with the exception that only $10 \mu l$ undiluted urine were taken for assay. The standard curve was constructed from 9 points containing 1000 , $700,500,400,300,200,100,80$ and 60 pg authentic testosterone-17 $\beta$-glucuronide (kindly donated by the M.R.C. Steroid Reference Collection, Westfield College, London NW3), in $100 \mu \mathrm{l}$ buffer $(0.01 \mathrm{M}$-Tricine-buffered saline, $\mathrm{pH} \mathrm{7.0)}$. The labelled antigen (1,2(n)-tritiatedtestosterone-17ß-glucuronide; sp. act. $57 \mathrm{Ci} / \mathrm{mmol}$ ) was purchased from New England Nuclear Corp., Boston, Massachusetts, and the antiserum was raised in a rabbit against testosterone-17ß-glucuronyl-6-bovine thyroglobin. The specificity of the antiserum has been assessed by comparing the amounts of related compounds that are required to reduce the initial binding of $\left[{ }^{3} \mathrm{H}\right]$ testosterone- $17 \beta$-glucuronide by $50 \%$. In this test the cross-reaction with testosterone was $50 \%$ but testosterone-17 $\alpha$-glucuronide, testosterone-17 $\beta$-sulphate, androsterone-3 $\alpha$-glucuronide and aetiocholanolone-3 $\alpha$-glucuronide all had values of $<1 \%$. No significant cross-reactions (i.e. $<0.01 \%$ ) were found with androstenedione, dehydroepiandrosterone, $5 \alpha$-androstane- $3 \alpha, 17 \beta$-diol or $5 \alpha$-dihydrotestosterone. Additional experiments with pooled urine from 30 mice indicated that the level of free testosterone was $<1.5 \mathrm{ng} / \mathrm{ml}$, i.e. $<3.8 \%(\mathrm{w} / \mathrm{w})$ of that excreted as the glucuronide.

The possible influence of non-specific binding due to urinary protein was also investigated in 10 samples of urine. One $10 \mu \mathrm{l}$ aliquot from each sample was diluted with buffer to $100 \mu \mathrm{l}$ and a second $10 \mu \mathrm{l}$ portion was dried at $100^{\circ} \mathrm{C}$ for $10 \mathrm{~min}$ before reconstitution in $100 \mu \mathrm{l}$ buffer for assay. This latter procedure ensured that protein was denatured. A Student's $t$ test for the difference between paired observations was applied to the results and showed that there was no significant difference between the two procedures (mean difference $=1.07 \mathrm{ng} / \mathrm{ml}$ ). The latter method was therefore subsequently adopted. Values from urine volumes between 10 and $25 \mu \mathrm{l}$ were shown to exhibit parallelism, but interference from urinary protein occurred with volumes of $>30 \mu$.

The method was further evaluated as described previously (Tyler et al., 1978) in terms of sensitivity, precision and bias. The mean values for these characteristics were: sensitivity 5 $\mathrm{ng} / \mathrm{ml}$; bias $+15 \%$; optimal conditions variance $9.9 \%$ and routine conditions variance $15.0 \%$. The analysis of $10 \mu \mathrm{l}$ distilled water gave a mean blank equivalent to $3.2 \mathrm{ng} / \mathrm{ml}(n=20)$, but this value was below the sensitivity of the assay and was not significantly different from zero. Creatinine was determined with a colorimetric test kit (Boehringer Corporation, Lewes, East Sussex, U.K.). The results were expressed as $\mathrm{ng}$ testosterone-17 $\beta$-glucuronide/ml urine or $\mathrm{ng}$ testosterone-17/-glucuronide/mg creatinine.

\section{Experiments}

Metabolism of $C_{19}$ steroids. Female mice (30) were each given a subcutaneous bolus of $50 \mu \mathrm{g}$ testosterone, androstenedione or dehydroepiandrosterone (Sigma (London) Chemical Co., Ltd, Poole, Dorset, U.K.) in $100 \mu \mathrm{l}$ lauric acid ethyl ester. The 10 animals in the control group received $100 \mu \mathrm{l}$ carrier only. Urine was collected immediately before the injections and 2, 4, 7, 24 and $26 \mathrm{~h}$ later.

Superovulation. Mice (14) were induced to superovulate by intraperitoneal administration of 
5 i.u. PMSG (Sigma) in $100 \mu \mathrm{l}$ saline $(9 \mathrm{~g} \mathrm{NaCl} / 1)$ at $16: 00 \mathrm{~h}$ on Day 1 of the study, followed $44 \mathrm{~h}$ later with 2.5 i.u. hCG in $100 \mu \mathrm{l}$ saline. A further group of 10 animals served as controls and received equivalent injections of saline only. Urine was collected immediately before the injection of PMSG (basal value, $0 \mathrm{~h}$ ) and 20,24, 44, 49, 68 and $73 \mathrm{~h}$ later. The histological state of the vaginal epithelium was followed by preparing a smear of a saline lavage at $0,24,49$ and $73 \mathrm{~h}$ and examining the unstained wet preparation. On Day 5 of the study each animal was killed by cervical dislocation and a record was made of the state of the uterus and the number of corpora lutea present in both ovaries.

Pregnancy. Females (8) were housed in pairs and induced to superovulate as described above. At $50 \mathrm{~h}$ after the PMSG injection 2 of the pairs were placed with a male of proven fertility for $18 \mathrm{~h}$; a vaginal plug (Day 1) was found for 3 of the females but all 4 became pregnant. Males were not introduced to the 2 control pairs of females. Until Day 16 urine was collected 4 times during a working day (approximately 09:00, 11:00, 13:00 and 15:00 h) and pooled for analysis. Urine was difficult to collect after Day 16 because of the advanced stage of pregnancy of the animal.

\section{Statistical analysis}

Since the raw data from each of the experiments approached a normal distribution, parametric statistics were used throughout. Initially an analysis of variance was computed on the data from each experiment and when significance was found Student's $t$ test was applied to assess differences between individual groups. A probability of $<0.01$ was taken as a significant difference.

\section{Results}

\section{Efficacy of urine collection}

An overall success rate of $>80 \%$ was achieved for urine collection so that a longitudinal study was maintained. An average of $67 \mu \mathrm{l} /$ sample (range 20-200 $\mu \mathrm{l}$ ) was obtained from an individual animal in a morning collection and $59 \mu \mathrm{l}$ (range 20-200 $\mu \mathrm{l}$ ) from a single afternoon collection. In the pregnancy study for which 4 fractions were pooled during a working day an average of $190 \mu \mathrm{l}$ could be collected (range 40-600 $\mu \mathrm{l}$ ).

\section{Effect of $C_{19}$ steroids}

As shown in Text-fig. 1, after the administration of testosterone, the mean \pm s.d. concentration of testosterone-17 $\beta$-glucuronide increased significantly $(P<0.01)$ within $2 \mathrm{~h}$ from $25.9 \pm 6.5$ to $71.7 \pm 12.9 \mathrm{ng} / \mathrm{ml}$. The corresponding values after the administration of androstenedione were $22.8 \pm 4.4$ to $81.8 \pm 7.8 \mathrm{ng} / \mathrm{ml}(P<0.001)$, and for dehydroepiandrosterone $23.4 \pm 2.7$ to $121.8 \pm 20.3 \mathrm{ng} / \mathrm{ml}(P<0.001)$. In the androstenedione- and dehydroepiandrosterone-treated animals testosterone-17 $\beta$-glucuronide values then decreased until by $24 \mathrm{~h}$ amounts were not significantly different from basal. The decrease in values after injection of testosterone was not as marked over the first $7 \mathrm{~h}$ as for the other two steroids, but by $24 \mathrm{~h}$ the amounts excreted were at basal levels. The output of testosterone-17 $\beta$-glucuronide over the first $7 \mathrm{~h}$ after the injection of dehydroepiandrosterone $(247.3 \mathrm{ng} / \mathrm{ml}$ per $7 \mathrm{~h}$ ) was greater than after testosterone or androstenedione (194.5 and $170.1 \mathrm{ng} / \mathrm{ml}$ per $7 \mathrm{~h}$ respectively). The response of each individual animal was similar in each group with the maximal increase occurring at $2 \mathrm{~h}$ and ranging between 2.8 and 5.3 times the basal values. In the control group there was also a statistically significant increase over the basal value $7 \mathrm{~h}$ after the injection of carrier from $20.7 \pm 5.2$ to $33.8 \pm 7.7 \mathrm{ng} / \mathrm{ml}(P<0.01)$, but this was insignificant compared to that in the experimental groups. 


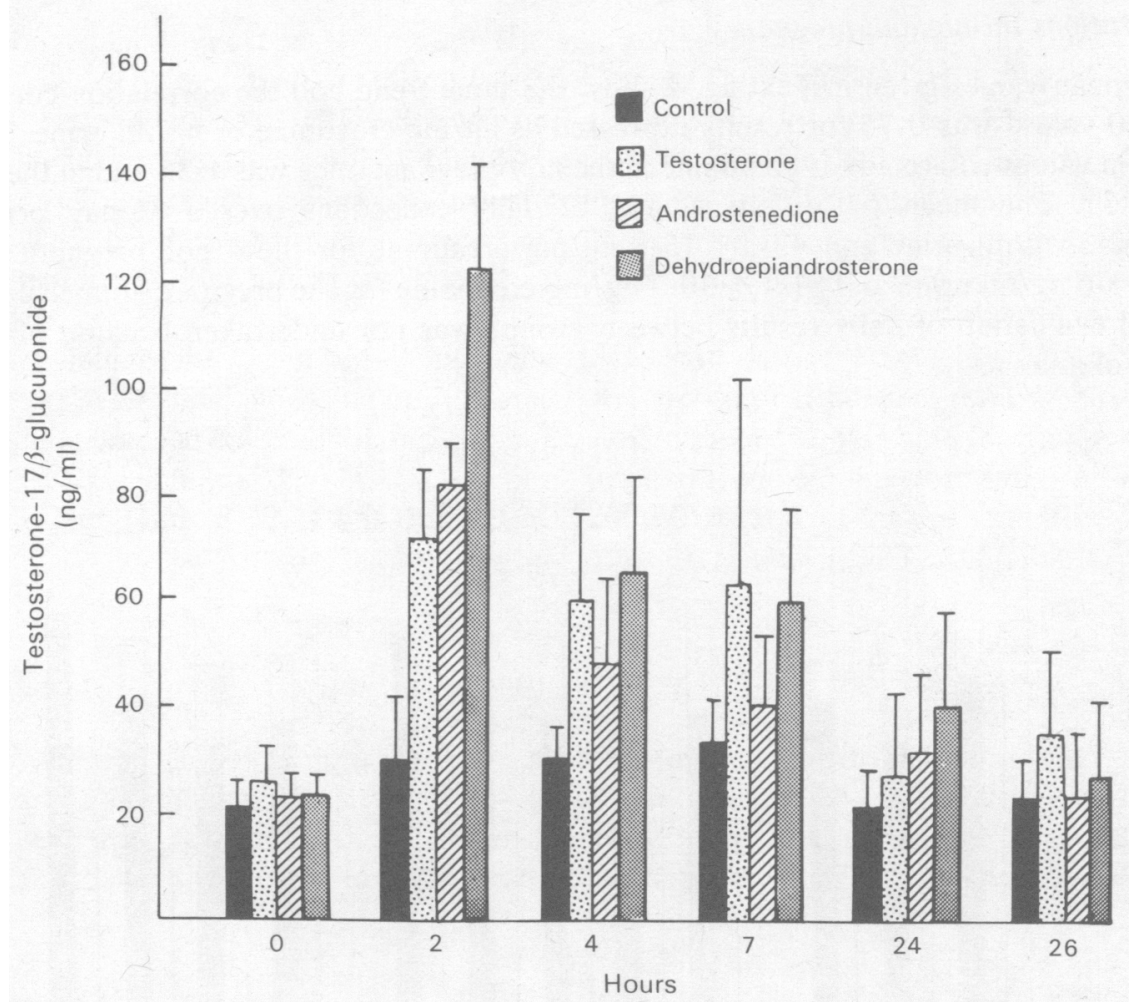

Text-fig. 1. Mean \pm s.d. concentrations of testosterone-17 $\beta$-glucuronide in the urine of mice treated with $50 \mu \mathrm{g}$ of the $\mathrm{C}_{19}$ steroid indicated or the vehicle alone (controls).

\section{Effect of superovulation}

Most of the mice given PMSG and hCG passed from dioestrus into pro-oestrus on the afternoon of Day 3, and to oestrus on Day 4. The control animals remained in dioestrus throughout the period of the experiment, confirming the observations of Whitten (1966) that sexually mature nulliparous mice housed together may show persistent dioestrus.

Corpora lutea were observed only in the ovaries of the experimental animals. In addition, the uterine horns were hyperaemic and distended in the experimental group, but collapsed and anaemic in the control animals. There were no significant differences $(P>0.01)$ in the concentrations of testosterone-17 $\beta$-glucuronide in the urine of control mice during the experiment (Table 1) but in the experimental mice maximal values occurred during the periovulatory period (5-24 h after hCG). When values for the 2 groups were compared for each time, there was a significant increase $(P<0.005)$ only at $49 \mathrm{~h}$. There was no significant difference between the results expressed as $\mathrm{ng} / \mathrm{ml}$ urine or $\mathrm{ng} / \mathrm{mg}$ creatinine.

Table 1. The mean ( \pm s.d.) values for urinary testosterone-17ß-glucuronide ( $\mathrm{ng} / \mathrm{ml}$ urine) during induction of superovulation in mice by injection of PMSG at $0 \mathrm{~h}$ and hCG $44 \mathrm{~h}$ later

\begin{tabular}{lccccccc}
\hline Mice (N) & $0 \mathrm{~h}$ & $20 \mathrm{~h}$ & $24 \mathrm{~h}$ & $44 \mathrm{~h}$ & $49 \mathrm{~h}$ & $68 \mathrm{~h}$ & $73 \mathrm{~h}$ \\
\hline Controls (10) & $47.4 \pm 17.9$ & $55.4 \pm 18 \cdot 1$ & $53.9 \pm 29.6$ & $47.4 \pm 24.1$ & $45.4 \pm 20.2$ & $57.9 \pm 24.1$ & $71.9 \pm 19 \cdot 1$ \\
Treated (14) & $42.2 \pm 20.7$ & $37.2 \pm 17.7$ & $48.7 \pm 19.3$ & $54.3 \pm 20.5$ & $77.5 \pm 23.2 *$ & $71.6 \pm 28.6 \dagger 63.5 \pm 19.0$ \\
\hline
\end{tabular}




\section{Concentrations throughout pregnancy}

The mean values given in Text-fig. 2 show the same trend and the correlation coefficient, $r$, for the 90 values was 0.75 for results expressed as $\mathrm{ng} / \mathrm{mg}$ creatinine or $\mathrm{ng} / \mathrm{ml}$ urine. The mean increase in values corrected for creatinine in the non-pregnant mice was 1.38 and in the pregnant group 1.31 . The mean ( \pm s.d.) values for 12 daily collections over a 16-day period were $30.7 \pm 12.3 \mathrm{ng} / \mathrm{ml}$ urine and $42.3 \pm 15.8 \mathrm{ng} / \mathrm{mg}$ creatinine for the 4 non-pregnant mice and $61.8 \pm 11.6 \mathrm{ng} / \mathrm{ml}$ urine and $81.1 \pm 30.7 \mathrm{ng} / \mathrm{mg}$ creatinine for the pregnant animals. A detailed statistical evaluation of daily results between groups was not undertaken because of the small numbers of animals.

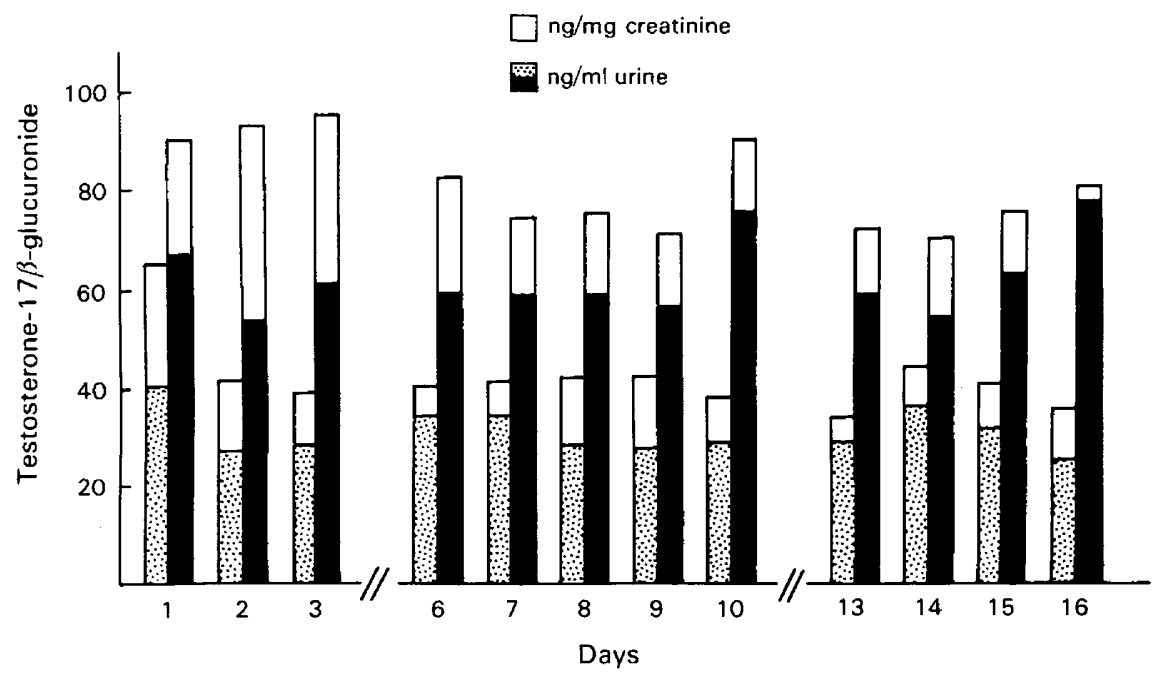

Text-fig. 2. The mean concentrations of testosterone-17 $\beta$-glucuronide in urine from 4 nonpregnant (stippled columns) and 4 pregnant (solid columns) mice.

\section{Discussion}

These results support and extend the earlier findings that the collection of serial samples of urine from female mice is a practical proposition. The measurement of testosterone-17 $\beta$-glucuronide in $10 \mu \mathrm{l}$ undiluted urine means that, to date, 3 compounds (testosterone-17 $\beta$-glucuronide, pregnanediol-3 $\alpha$-glucuronide and creatinine) can be measured in as little as $40 \mu \mathrm{l}$ urine-less than the average volume obtained for a single collection. As previously found, the same general information can be obtained from the results whether or not a correction for urine volume is applied. Consequently, where access to an autoanalyser is limited, an indication of hormone status can be obtained by expressing the results directly as $\mathrm{ng} / \mathrm{ml}$ urine.

Androgen metabolism in women has been studied in detail (see review by Sommerville \& Collins, 1970) and the concentration of urinary testosterone-17 $\beta$-glucuronide has been used as an index of the production of $\mathrm{C}_{19}$ steroids containing a 17 $\beta$-hydroxyl group (Hennam, Collins \& Sommerville, 1973; Tresguerres \& Tamm, 1979). The biosynthesis and metabolism of $C_{19}$ steroids can, however, be influenced by a number of factors, which are little known in the mouse. The basal values (i.e. those at $0 \mathrm{~h}$ ) for the data presented in Table 1 and Text-fig. 1 are significantly different from each other, suggesting that there may also be an age- and batch-related difference in the excretion of testosterone-17 $\beta$-glucuronide between animals. Furthermore, the fact that a slight, but significant, increase in the metabolite occurred in the 
control animals $7 \mathrm{~h}$ after the injection of carrier may indicate that the animals were stressed, with a concomitant increase in adrenocortical activity, or the increase may be accounted for by nycthemeral variation. The results after $\mathrm{C}_{19}$ steroid administration provide further evidence that the determination of urinary testosterone-17 $\beta$-glucuronide may reflect androgenic status, because an immediate increase in the concentration of the metabolite occurred after the injection of steroid. That the output of the metabolite increased more over the first $7 \mathrm{~h}$ after the injection of dehydroepiandrosterone than of testosterone or androstenedione might reflect its position in the biochemical pathway, as a precursor of both androstenedione and androst-5-ene-3 $\beta, 17 \beta$-diol.

The increased values for testosterone-17$\beta$-glucuronide about the time of ovulation agree with findings for the rat that plasma testosterone concentrations may increase at this time (Dupon \& Kim, 1973; Nequin, Alvarez \& Schwartz, 1975). Barkley, Michael, Geschwind \& Bradford (1977) have reported an increase in peripheral plasma testosterone values during mid-pregnancy in the mouse, and a similar pattern has been described for the rat (Weizenbaum, Adler \& Ganjam, 1979). In the present study there was an apparent increase in mean values for testosterone-17 $\beta$-glucuronide expressed as $\mathrm{ng} / \mathrm{ml}$ on Day 10 of gestation, but more animals need to be studied. Also, it is more difficult to collect urine in late pregnancy (because the pressure on the bladder probably increases the frequency of micturition) so correction of values for creatinine clearance may be more critical. These studies indicate that the determination of testosterone-17 $\beta$-glucuronide in serial samples of urine from female mice may serve as an overall index for monitoring testosterone output within an individual animal, but further studies will be required to determine the relative contributions of different circulating $\mathrm{C}_{19}$ steroids to this index.

\section{References}

Barkley, M.S., Michael, S.D., Geschwind, I.I. \& Bradford, G.E. (1977) Plasma testosterone during pregnancy in the mouse. Endocrinology 100, 14721475.

Dupon, C. \& Kim, M. (1973) Peripheral plasma levels of testosterone, androstenedione and oestradiol during the rat oestrous cycle. J. Endocr. 59, 653-654.

Hennam, J.F., Collins, W.P. \& Sommerville, I.F. (1973) Radioimmunoassay of testosterone glucuronide. Steroids 21, 285-306.

Louvet, J.P., Harman, S.M., Schreiber, J.R. \& Ross, G.T. (1975) Evidence for a role of androgens in follicular maturation. Endocrinology 97, 366-372.

Louvet, J.P., Bayard, F., Pujol, A. \& Toulouse, C.B. (1976) Interaction of androgens and gonadotrophins within the ovary of the immature rat. Annls Endocr. 37, 487-488.

Nequin, L.G., Alvarez, J. \& Schwartz, N.B. (1975) Steroid control of gonadotrophin release. J. Steroid Biochem. 6, 1007-1012.

Payne, R.W. \& Runser, R.H. (1958) The influence of estrogen and androgen on the ovarian response of hypophysectomized immature rats to gonadotropins. Endocrinology 62, 313-321.

Payne, R.W., Hellbaun, A.A. \& Owens, J.N. (1956) The effect of androgens on the ovaries and uterus of the estrogen treated hypophysectomized immature rat. Endocrinology 59, 306-316.

Peters, H., Sorensen, I.N., Byskov, A.G., Peterson, T. \& Krarup, T. (1970) The development of the mouse ovary after testosterone propionate injection on day 5. In Gonadotrophins and Ovarian Development, pp. 351-361. Eds W. R. Butt, A. C. Crooke \& M. Ryle. Churchill Livingstone, London.

Sommerville, I.F. \& Collins, W.P. (1970) Indices of androgen production in women. In Advances in Steroid Biochemistry and Pharmacology, pp. 269314. Ed. M. H. Briggs. Academic Press, London.

Tresguerres, J.A.F. \& Tamm, J. (1979) Urinary and plasma testosterone glucosiduronate measurement by a simple RIA method. J. Steroid Biochem. 11, 143-146.

Tyler, J.P.P., Edwards, W.R. \& Collins, W.P. (1978) The measurement of steroid glucuronides in urine from mice to monitor gonadal function. 1. Pregnanediol$3 \alpha$-glucuronide as an index of progestogen output. Endocrinology 103, 2342-2348.

Weizenbaum, F.A., Adler, N.T. \& Ganjam, V.K. (1979) Serum testosterone concentrations in the pregnant rat. J. Steroid Biochem. 10, 71-74.

Whitten, W.K. (1966) Pheromones and mammalian reproduction. Adv. Reprod. Physiol. 1, 155-177. 